\title{
Da hiper ficção ao hiper documental: impasses entre ficcional e documental na representação do erotismo indígena no documentário Hiper mulheres
}

\author{
José Carlos Felix ${ }^{1}$ \\ Universidade do Estado da Bahia \\ Francisco Gabriel De Almeida Rego ${ }^{2}$ \\ Universidade do Estado da Bahia
}

Resumo: O presente trabalho analisa o documentário Itãokuegü: as hiper mulheres (2011), de Takumã Kuikuro, Carlos Fausto e Leonardo Sette, a fim de refletira maneira pela qual o cinema documental vem abordando expressões culturais de grupos indígenas, particularmente, no que diz respeito a tensão existente entre a representação cinematográfica documental de cunho etnográfico e o registro de fenômenos culturais centrados no conceito das poéticas orais.Em seguida, examinamos questões acerca do erotismo representado pelo documentário no sentido de problematizar as estratégias de autorrepresentação indígenas, entre elas o feminino, inscrito por meio de antinomias como erotismo/norma sexual e narrativas ficcionais/registro documental.

Palavras-chave: Documentário; ficção; poética oral; erotismo.

${ }^{1}$ Docente Adjunto da Universidade do Estado da Bahia. professor permanente do Programa de Pós-Graduação em Crítica Cultura. Pesquisador pelo grupo Pós-Teoria, UNEB/PÓS-CRÍTICA.

${ }^{2}$ Mestrando em Crítica Cultural - UNEB/Campus II. Bolsista da Fundação de Amparo à Pesquisa do Estado da Bahia (FAPESB). 


\title{
Hyper fiction to hyper documentary: impasses between fictional and documentary in the representation of indigenous eroticism in the documentary Hiper mulheres
}

\begin{abstract}
This paper analyses the documentary Itãokuegü: as hiper mulheres (2011), by Takumã Kuikuro, Carlos Fausto e Leonardo Sette focusing on how documental cinema has been approaching cultural expressions of indigenous peoples placing particular attention on the tension established between ethnographic documental film representation and the recording of cultural phenomena grounded on the concept of oral poetics. In addition to that, the discussion also aims at examining other issues related to eroticism represented by the documentary in order to problematize strategies of Indians self-representation regarding the representation of feminine inscribed by antinomies such as eroticism/sexual norm and fictional narratives/documental record.
\end{abstract}

Keywords: Documentary; fiction; oral poetics; eroticism.

\section{Hiper ficción a lo hiper documental : impasses entre ficción y documental en la representación del erotismo indígena en lo documental mujeres Hiper mulheres}

Resumen: El presente trabajo investiga el documental Itãokuegü: as hiper mulheres (2011), de Takumã Kuikuro, Carlos Fausto y Leonardo Sette, con el propósito de reflexionar sobre la manera por la cual el cine documental viene abordando expresiones culturales de los grupos indígenas, principalmente, con respecto a la tensión existente entre la representación cinematográfica de los documentales de carácter etnográfico y el registro de los fenómenos culturales centrados en el concepto de las poéticas orales. Luego, investigamos cuestiones acerca del erotismo representado por el documental a fin de problematizar las estrategias de representación propias de los indígenas, entre ellas el femenino, inscrito por medio de antinomias tales como erotismo/norma sexual y narrativas ficcionales/registro documental.

Palabras clave: Documental; ficción; poética oral; erotismo. 


\section{Realismo,etnografia e voz documental}

A representação cinematográfica pode-se constituir como um espaço de tensão, dependendo do tipo de relação que o filme estabeleça com o objeto e temática em questão, bem como as demais tensões internas de caráter formal, inerentes a construção narrativa seja ela de cunho ficcional ou mesmo documental. No sentido de abarcar ao máximo as contradições e interdições constitutivas da experiência humana e em seu compromisso com a exploração da "realidade", o gênero cinematográfico documentário, a rigor, instaura um espaço de tensão interna como externa, engendrado tanto pelo sistema que o abarca quanto pela relação com seus espectadores, seja inclusive mediada pela crítica - fundamental para construção dos valores que legitimarão seu status como expressão cultural. Ao mesmo tempo,o documentário é também muito mais do que o produto de uma construção exclusivamente autoral, a despeito da centralidade da figura do autor/diretor possa sugerir,uma vez que a própria noção de autoria estaria circunscrita dentro dessa relação do documentário dentro de um complexo sistema que abarca sua realização em produto cultural. Ademais, a maneira como o documentário se constrói, dentro de uma lógica da tensão dialética em suas estruturas, modula e afeta o olhar daquele que, por alguma razão, se propõem a observar determinado objeto ou evento constituído dentro do sistema/organização social. Do mesmo modo, tal constatação talvez assinale o fato de que, para o documentário, a própria noção de experiência humana só faça sentido diante dentro de um regime de tensão na qual observador e observados estejam intrinsicamente inseridos, constituindo uma complexa teia de relações que aproxima respectivamente sujeito e objeto.

Nesse sentido, escrever sobre um documentário, e, por conseguinte analisá-lo, é também apontar para seus engendramentos, decompô-lo e descrevê-lo em elementos menores dotados de autonomia, mas ainda amalgamados dentro de sua micro e macroestrutura. De qualquer forma, o gesto analítico da crítica tem por objetivo o esclarecimento dos funcionamentos de um determinado documentário (ou mesmo filme de ficção), dado o empenho em examinar os elementos que possibilitem a observação dentro da lógica desenvolvida, cabendo ao olhar de quem analisa reconstruir as relações, de modo a perceber dentro desse arranjo as formas pelo qual o documentário pode se relacionar a outras expressões e manifestações artísticas engendradas no âmbito da cultura.

Dentre os elementos formais fulcrais para a compreensão da lógica de estruturação de um produto audiovisual como o documentário, está a relação entre imagens e sons. Deve-se apontar então para o som e, por conseguinte, a voz, como o conjunto representativo a partir do qual o documentário se constrói. Se o filme é visto, é também perceptível dentro da dimensão sonora, sendo constituído naquilo que poderíamos chamar de uma instância sonora do filme, ou, como denominam os manuais técnicos do cinema, a banda sonora, em separação a uma ideia de visualidade. É bem verdade que, como qualquer outro produto audiovisual, o documentário é muito mais do que o simples arranjo e combinação entre som e imagem; sendo legitimado, a bem da verdade, pelo caráter relacional que cada uma dessas instâncias exerce em si e na outra. 
Dentro dessa perspectiva, a voz ganha uma conotação bem específica, pois tenciona e revela elementos fundamentais como: enunciação, recepção, língua, discurso e elementos narrativos como a verossimilhança e ambientação. A articulação entre o som e a voz particularmente desenvolvidos em um gênero marcadamente "realista" como o documentário é um atributo utilizado pelo autor/diretor/documentarista na construção do produto, carregando e revelando peculiaridades que fazem daquele um produto complexo - seja na sua relação com a cultura de massa e indústria cultural ou em função de uma "linguagem", "sintaxe" e "léxico", que, na relação com as expressões populares e tradicionais, acabam por lançar um novo olhar, por meio da reconfiguração daquilo que seja velho, tradicional ou popular (ADORNO, 1994).

Para Nicholls, cada documentário tem uma forma específica de lidar com a voz e, assim como a voz que fala, articula e modula uma ideia de estilo. No livro Introdução ao documentário (2005), o autor apresenta a voz como um critério para se definir diferente tipos de documentário. Para ele, a voz é entendida como um conjunto de elementos não apenas sonoros, mas também visuais que dotados de uma de expressividade que, de modo organizado e hierarquizado, interferem na arquitetura do documentário, produzindo um efeito característico próprio das realizações documentais. Ademais, a voz configura-se também como mecanismo basilar para estabelecer distinções nos diferentes tipos de gênero cinematográfico,instaurando inclusive marcas significativas entre o cinema ficcional e documental. Nesse sentido, dentro da dimensão da voz, e para além da noção tradicional de voz constituída única e exclusivamente por elementos sonoros, poder-se-ia identificar uma outra dimensão intimamente ligada à escolha das imagens que, por sua vez, articulamos arranjos dos recursos visuais e sonoros imbricados na construção da estrutura fílmica documental. Essa voz estaria subsumida à forma como o cineasta/documentarista busca expressar uma determinada perspectiva, ao construir um determinado ponto de vista do objeto, sujeito ou universo representado3. É dentro dessa perspectiva que Nichols identifica ainda seis modos de uso da voz dentro do cinema documental, a saber: poético, expositivo, participativo, observativo, reflexivo e performático (2005: 135).

Segundo o autor, o modo poético é caracterizado pelo sacrifício às convenções tradicionalmente vinculadas ao documentário, sendo perceptível na montagem dos planos não convencionais, que buscam temporalidades $\mathrm{e}$ espacialidades específicas, expandindo os conceitos e limites do que é documentário, como porta voz da realidade. O documentário poético se apropria do tempo histórico, para transformá-lo em outras temporalidades. Nesse tipo de documentário, sujeito e sociedade estariam correlacionados de modo profundo em estado de trânsito contínuo, uma vez que, com a suspensão das fronteiras, as vozes perdem seu caráter identitário, não havendo assim uma definição clara entre quem narra e quem ouve (2005: 138-142). Já o modo expositivo é marcado pela ideia de voz de autoridade, por meio do uso do convencional do recurso de voice-over, criando o efeito de um orador-narrador que não aparece, mas que se relaciona diretamente com o objeto apresentado. Algo muito próximo da lógica televisiva firmada na relação entre emissor e receptor. Esse tipo tem por característica o uso amiúde expositivo do documentário para retratar uma realidade. Nesse caso, essa "Voz de Deus", seria

3 Temporalidade e espacialidade também são outros elementos formais contidos nessa articulação. 
a referência mais explícita a noção convencional do narrador, caracterizada pela centralização da voz narrativa (2005: 142-146).

No modo participativo, por sua vez, temos o envolvimento do cineasta de forma mais efetiva. Esse modo tem como principal modulação criar a sensação de participação e engajamento direto por parte do espectador, inserindo-o em uma determinada dimensão de realidade, de modo a emular a experiência de vida de outras pessoas a partir do emprego de métodos, técnicas e instrumentos comuns à antropologia e sociologia. O documentário participativo parte da premissa de um envolvimento maior, quase corpóreo por parte do cineasta, para construir um efeito de testemunho, afastando-se do uso da tradicional voiceover ou de qualquer "mediação poética" (2005: 153-162).

No modo reflexivo imperaria o questionamento acerca dos métodos de abordagem do cinema, em um questionamento do real poder do documentário de representação do mundo. Esse modo intenta uma reflexão do mundo e do próprio cinema como forma de documentar uma realidade contraditória. Sendo assim, o documentário se estrutura a partir de uma lógica contraditória como estratégia de chamar atenção das contradições do universo retratado. Nesse sentido, os trabalhos de Eduardo Coutinho, mais precisamente, o filme Jogo de Cena (2007) e Cabra marcado para morrer (1984) são interessantes exemplos dessa forma de documentário. Esses documentários carregam um tom metalinguístico, tratando de questões como as limitações de representação do outro, tentando "nos convencer da autenticidade ou da veracidade da própria representação" (2005: 162-168). O documentário performático é marcado pela subjetividade e por um caráter autobiográfico, investindo preferencialmente em dimensões afetivas e subjetivas, ao possibilitar o acesso a uma compreensão de mundo baseados em sujeitos específicos, como por exemplo, o próprio cineasta. Segundo Nichols, o documentário performático, por ser subjetivo, instaura uma sensação de magnitude do local, do específico e do concreto. A performance estimula o pessoal, pois a voz que constrói é pessoal, inserindo-se como sujeito em uma realidade específica, ao mesmo tempo em que revela as sensações e impressões, colocando assim o documento fílmico na condição de interprete desse mundo que o cerca (2005: 169-176).

Por fim, a categoria denominada por Nichols como o modo observativo, e que nos interessa para examinar o documentário Itãokuegü: as hiper mulheres, pode ser sintetizado na seguinte pergunta: é possível que o cineasta documental apenas observe, sem intervir explicitamente no objeto filmado? A pergunta traz à baila uma questão fulcra à cerca da relação do cinema documental com o objeto investigado, além das fronteiras e limites do documentário enquanto gênero cinematográfico per se, considerando sua construção representativa de uma determinada realidade. A busca por um olhar legítimo para realidade retratada parece guardar relação com a pureza, imparcialidade ou objetividade do olhar, imprimida amiúde aos produtos documentais de caráter antropológico. Outro ponto fundamental recai sobre o fato de o caráter observativo do documentário estar diretamente relacionado às transformações tecnológicas que possibilitam uma maior flexibilidade na realização do documentário, a exemplo das câmeras e da edição digital. Por outro lado, o simples advento de um avanço tecnológico como a redução do tamanho das câmeras poderia influenciar de sobremaneira o papel do próprio documentarista como um sujeito em trânsito (2005, 146-152). 
A título de ilustração dessa questão, podemos apontar as transformações tecnológicas que aproximam o documentário observativo de outras realizações que a partir dos anos de1960 produziram uma forma característica de cinema ou filme documental chamado de cinema verdade (cinema vérité), ao evidenciar a experiência fílmica em consonância com a realidade tal como é observada. Os filmes dos cineastas da chamada "trindade neo-realista", ou "núcleo duro neorealista”, Rossellini, De Sica, Zavattini-Visconte, atraíam a atenção das plateias italianas e internacionais por oferecerem um novo testemunho acerca das consequências do pós-guerra, rompendo com a tradição fílmica caligrafista vigente, chamada de câmera-stylo. O propósito era de fato romper com o estilo de apresentação/representação "naturalizada" de uma realidade que, através de recursos técnicos como montagem, fotografia, luz, cenários em estúdios e, sobretudo, histórias pertencentes a gêneros dotados de convenções narrativas de fácil compreensão, esforçava-se por "parecer verdadeira" - questão problematizada por Metz em "A respeito da impressão de realidade no cinema" (2007: 15-28). No livro O cinema (1991), crítico André Bazin discorre a respeito daquilo que ele considera o caráter evolutivo do realismo cinematográfico, quando comparado com outras formas de representação em relação à verossimilhança. Seu argumento, exposto de modo mais detalhado no capítulo "A evolução da linguagem cinematográfica" (1991:66-82), analisa as implicações e diferenças no sentido do filme engendradas pelas escolhas estéticas feitas por cineastas que priorizam a "imagem" ou que se voltam para a "realidade". Bazin elabora sua crítica à primeira categoria, expressa nos recursos de montagem da tradição do cinema soviético e na exacerbada estilização e distorção da perspectiva característica do expressionismo alemão. Em sua opinião, os recursos de montagem produzem uma fragmentação espaço-temporal do mundo, que, além de provocar uma excitação, obstruem a criação de múltiplos planos da realidade em relevo produzidos, em contraposição, pela sensação de profundidade obtida na longa duração de uma plano-sequência (recurso amplamente explorado posteriormente pelo cinema documental).

Contudo, nota-se que, a despeito de questões formais, é de fato em um contexto no qual a realidade é visivelmente estranha àquela do sujeito observador, que o realismo documental surge como um potente meio de expressão, não apenas para descrever e registrar diferenças sociais, mas sobretudo para mobilizar grupos e indivíduos no sentido de pensar e refletir sobre a diferença. Em certo sentido, o estranhamento resultante do confronto com o diferente reforça a sensação de que a "verdade" existe e funciona como uma força catalisadora que busca na verossimilhança da representação um meio de assegurar a existência das coisas como elas de fato são- como se apenas o impacto causado pela descrição de uma aparente condição de diferença fosse suficiente para aproximá-la ou torná-la menos estranha. Nesse sentido, na esteira do signo da representação pela imagem que dominou o século passado, os meios visuais tornaram-se rapidamente um potente recurso de captura das mais variadas expressões culturais. No cinema, foi certamente o refinamento das técnicas de duplicação dos objetos empíricos - como o advento do filme sonoro e, posteriormente, o desenvolvimento da película em cores - que forneceram as condições necessárias para uma discussão teórica acerca do caráter mimético e realista das artes visuais. De certa forma, o surgimento de uma corrente teórica dentro dos recém-iniciados estudos de cinema, denominada de "teoria realista do cinema", representou também a demarcação 
de uma nova posição teórica contrária à tendência de orientação formativa que dominou esse campo nas primeiras décadas do século XX.

Tanto realismo cinematográfico quanto documental são, contudo, termos problemáticos, já que abarcam uma miríade de diferentes tendências e nuances, para não mencionar uma longa história com suas próprias ramificações em todas as artes representacionais. Em relação ao cinema, duas fontes opostas devem ser mencionadas. A primeira vem das primeiras experimentações de Sergei Eisenstein sobre a montagem fílmica, que desnudou a artificialidade inerente ao meio e mostrou que o realismo não é um sinônimo para espontaneidade. Como a percepção, como pretendemos discutir nas seções abaixo, é desde sempre estruturada, o realismo não deve ser entendido como um inimigo da técnica, e uma vez que o cinema possui um potencial quase ilimitado para a montagem, poderia ser um veículo privilegiado para o registro e captura da realidade social.

\section{A tensão entre voz poética e os protocolos documentais em Itãokuegü: as hiper mulheres}

É dentro da categoria de documentário observativo estabelecida por Nichols (2005: 147) que iremos abordar o documentário Itãokuegü: as hiper mulheres (2011), de Takumã Kuikuro, Carlos Fausto e Leonardo Sette ${ }^{4}$. Entre outras questões que o documentário aborda, a sexualidade indígena é apresentada de um ponto completamente distinto de onde estaria localizado o espaço de recepção - ou seja, dos padrões normativos da sexualidade ocidentais. Nesse sentido, nota-se já nas primeiras cenas do documentário um esforço em confrontamento o olhar do espectador com o olhar indígena para a questão particular do erotismo, ao apresentar a mulher como elemento ativo no jogo sexual estabelecido no povo kuikuro. No documentário, por meio da representação cultural de caráter tradicional denominada de Jamurikumalu, as mulheres realizam uma cerimônia na qual assumem a posição de agentes, sendo conferido a elas o direito de buscar e, até mesmo escolher, os homens para a realização do ato sexual, chegando, em alguns momentos, a brigar com estes, com finalidade de obrigá-los a realização de práticas sexuais.

Poder-se-ia pensar assim em uma metáfora na qual o erotismo indígena seria o tema central, em uma precipitada comparação com a sociedade contemporânea. Tal metáfora estaria assentada na percepção de que, para se representar o erotismo desenvolvido por meio da experiência do mito, expresso pelo Jamurikumalu, é fundamental que se parta de um sistema de significações que legitimaria a produção do discurso na construção fílmica documental, uma vez que o erotismo indígena é apresentado por uma lógica inversamente contrária àquela do erotismo ocidental. Para tanto, os realizadores do documentário acompanharam durante vários meses o cotidiano dos habitantes de uma aldeia indígena, no Alto Xingu (MT), no qual as mulheres se preparam um ritual no qual irão sobrepor-se aos homens, assumindo o protagonismo da aldeia, desafiando os homens, utilizando adornos e armas masculinas para participar de lutas tradicionalmente masculinas.

${ }_{4} \mathrm{O}$ agrupamento de três realizadores com formações distintas já seria em si, matéria para uma outra discussão sobre a realização do documentário que articula pontos de vista ou vozes marcadamente distintas: TakumãKuikuro, além de cineasta, tem descendência indígena, Carlos Fausto, além de cineasta, é antropólogo e Leonardo Sette cineasta. Contudo a questão foge ao propósito do recorte e foco estabelecido para esse artigo. 
Ao empregar estratégias de narração etnográficas, depoimentos, entrevistas e câmera circulando por todos os cantos da aldeia, o documentário aproxima-se, explora e confere maior ênfase a voz feminina, seja no sentido literal quanto do metafórico, como forma de assinalar e representar o mito envolvido na representação do Jamurikumalu, também chamado também de yamurikumã. A sensação de credibilidade produzidas pelas vozes é alcançada pela aproximação dessas com a ideia de voz, síntese da memória coletiva. Dessa forma, o documentário apresenta uma negociação entre som e imagem, tendo por base a identificação dos elementos sonoros com as imagens apresentadas, com a finalidade de apresentar uma ligação direta entre quem fala e quem está falando, já que as vozes estão inseridas dentro do espaço diegético. Outra estratégia de adensamento do caráter etnográfico do documentário ocorre pela subtração da narração em voice-over, muito comum no gênero documental. Nesse caso, tem-se a impressão de que a narração dos episódios é contada pelos próprios indígenas, em sua língua, sendo a mediação feita por legendas. Contudo, é interessante notar tanto a maneira que os documentaristas empregam o uso recorrente da câmera na mão, o que reforça o caráter de imersão na comunidade, quanto à maneira como a narrativa se alinhavam por meio de uma montagem meticulosa que alterna amiúde entre imagens de plano fechado (imagem 1)e plano geral (imagem 2). Ademais, ao optar pelo uso da câmera na mão e pelo plano geral, o documentário imprime uma carga de descrição e imersão à narrativa. Tais características sugerem o recurso bastante comum no trato das imagens: o uso de entrevistas (imagem 3), que, juntamente com a captação do som de forma direta (imagem 4),evidenciam a relação estabelecida entre emissor e a imagem definida pela ideia do registro antropológico.

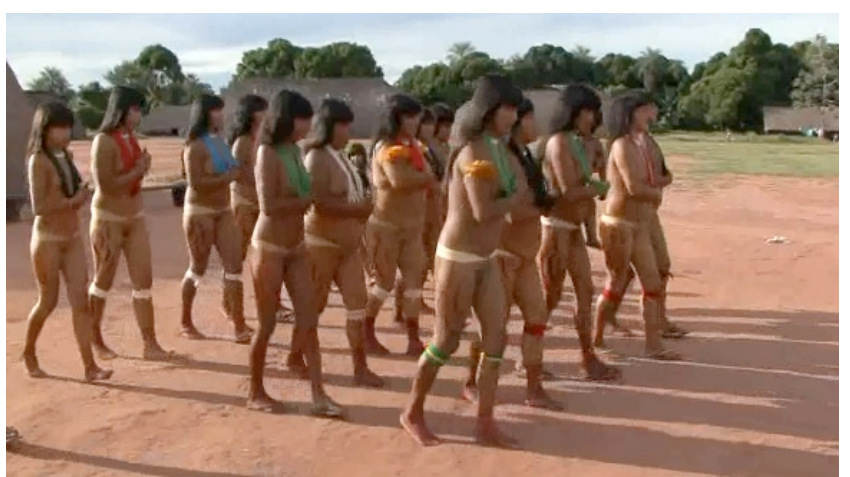

(Imagem 1) Preparação para o Jamurikumalu

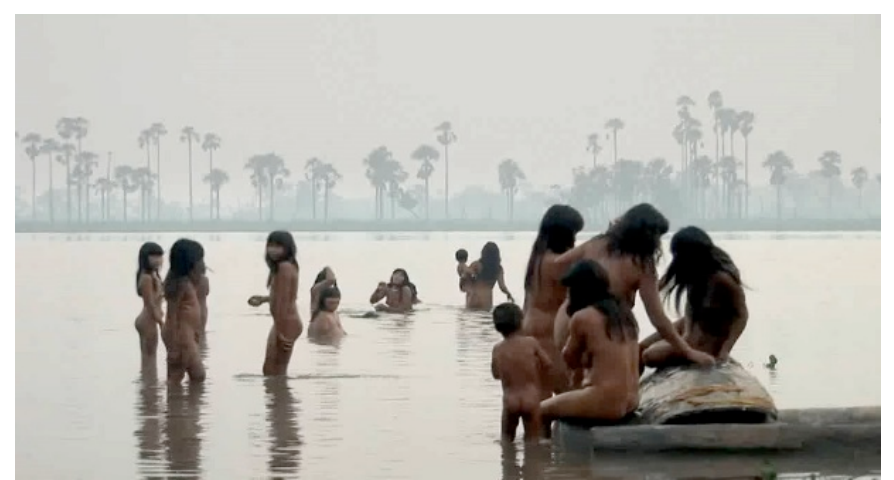

(Imagem 2) Plano geral - As mulheres do povo kuikuro 


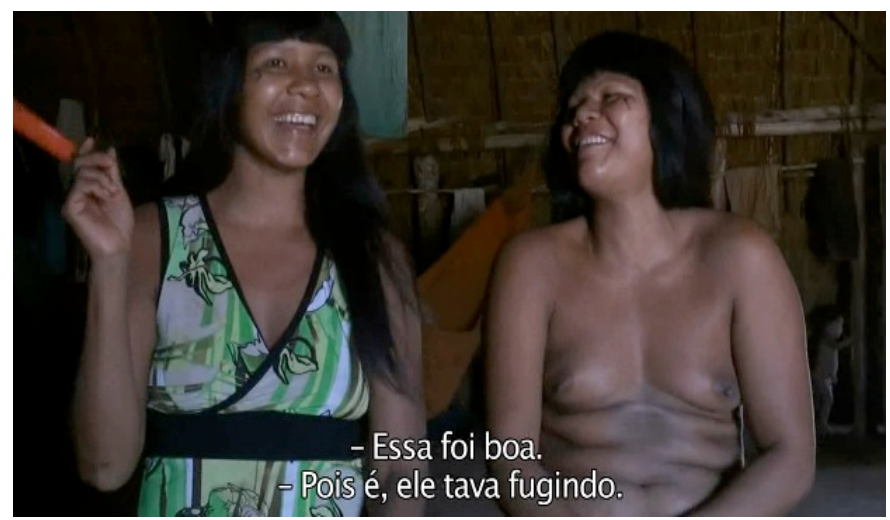

(Imagem 3) Entrevista - Legendas - apresentação do mito

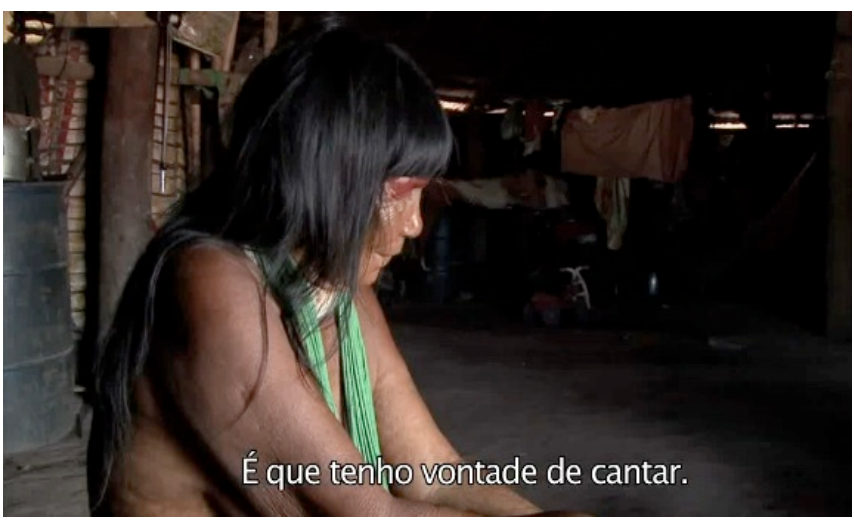

(Imagem 4) Entrevista - capitação direta da voz

Um outro aspecto salutar a ressaltar no documentário é o papel conferido ao mito na construção da voz na narrativa. As vozes são apresentadas nas dependências das narrativas baseadas no mito, pois o que é contado pelas vozes das narradoras é o que a tradição possibilita. É justamente nesse sentido que o documentário instaura uma tensão entre esse falar narrativo e tradicional com a experimentação individual de alguns dos membros frente ao cotidiano da comunidade que, ao discorrem sobre a questão,assinalam as dificuldades na continuidade da transmissão dos conhecimentos tradicionais. Tal tensão é adensada à medida que os eventos, situações e dramas vividos pelas personagens da aldeia assumem dimensões narrativas tão ficcionais quanto documentais. O caráter narrativo-ficcional é construído de maneira tão indissociável do documental que,logo nas primeiras cenas do documentário, o espectador se depara com o seguinte drama posto na narração: com receio que sua esposa já idosa venha a falecer, um senhor pede a seu sobrinho que realize o Jamurikumalu, considerado o maior ritual feminino do Alto Xingu, para que ela possa cantar uma última vez. Tem-se assim o mote narrativo, ou linha dramática, que conduzirá o espectador durante boa parte do documentário. Ou seja, enquanto a câmera acompanha o drama pessoal da única cantora que de fato conhece todas as músicas do ritual e que se encontra gravemente doente, outra linha da narração centra-se nas demais mulheres do grupo começam os ensaios e os preparativos para o ritual Jamurikumalu.O constante enlaçamento e confronto entre as duas linhas narrativas adensa ainda mais a sensação de quão tênue se encontram as fronteiras entre a dimensão ficcional das histórias e dramas narrados em contrastada com o papel do documentário em abordar tanto os preparativos para o ritual quanto o cotidiano do povo kuikuro.

É nesse regime de tensão entre uma almejada "espontaneidade" constituída nas performances de tradição de expressividade oral e o controle característico dos protocolos cinematográficos documentais de cunho etnográfico que o documentário estabelece a construção de um diálogo entre a representação ficcional e a documental. Se para o documentário a representação dos atributos típicos do povo é o ponto legitimador da construção de uma narrativa documental de cunho etnográfico, ao abordar as peculiaridades de um determinado grupo por meio do registro do cotidiano dessa comunidade, por outro lado, o elemento ficcional constrói uma ambivalência que envolve a própria forma de narração do Jamurikumalu. Nesse sentido, fica a questão, até que ponto as expressões de cunho tradicionais registradas no documentário correspondem à realidade da comunidade? Tal pergunta parece estar na ordem 
da verossimilhança instaurada pelo Itãokuegü: as hiper mulheres, cujo papel preponderante fica a cargo da voz dos narradores.

A voz poética norteia o fio condutor da narrativa tanto do ponto de vista da ficção quanto do documentário. A voz que conta as narrativas e expressões tradicionais é a mesma que revela as intenções e testemunhos das personagens, e são construídas à semelhança da vida cotidiana do povo kuikuro (imagens $5 \mathrm{e}$ 6). Sendo assim, em que medida podemos falar em personagens? Esse questionamento ganha força quando comparamos a relação entre a voz tradicional e a voz documentada na construção narrativa do filme e percebemos que a construção da voz poética, profundamente ligada à tradição oral e memória, apesar do caráter etnográfico posto pelo documentário, é um elemento marcadamente ambivalente. Se, por um lado, essa voz pode ser observada como uma construção ligada às expressões orais, é também um elemento fundamental para construção ficcional e documental.

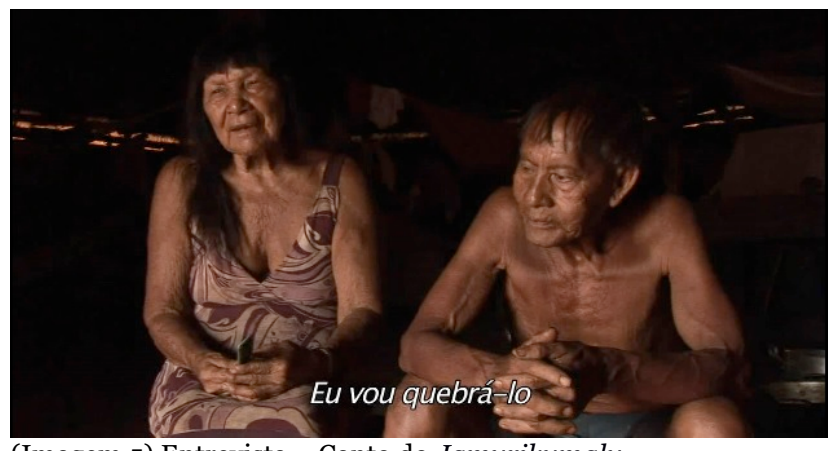

(Imagem 5) Entrevista - Canto do Jamurikumalu

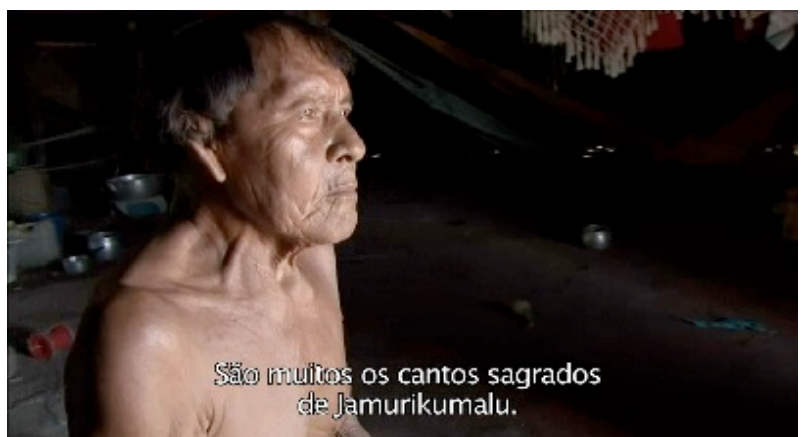

(Imagem 6) Plano sequência - Canto do Jamurikumalu

Do ponto de vista da ficção, o documentário encontra na voz poética um elemento fundamental para construção da verossimilhança: o apelo do tio ao sobrinho para que este realize o ritual antes que sua esposa, que conhece todos os cantos da tradição, assegurando assim a continuidade da tradição oral é tomado pelo documentário com ponto desencadeador da "trama narrativa". Enquanto que do ponto de vista do documentário, a voz pode ser definida como um elemento definidor do documentário observativo: em vários momentos, nada escapa ao olhar ubíquo da câmera (na mão) que passeia livremente pela aldeia, invade os lugares mais recônditos das ocas, adentra a formação de filas enquanto as índias ensaiam os cantos para o ritual. Do mesmo modo, a edição das imagens cumpre o papel de situar o espectador temporal e espacialmente: a exemplo da intercalação das cenas na noite em que as mulheres saem a caça dos possíveis parceiros com os depoimentos de alguns integrantes, em sua maioria mulheres quase em tom de confissão, acerca das impressões dos eventos da noite anterior.

Para Zumthor, a voz pode ser percebida dentro de algumas perspectivas básicas como o lugar simbólico e alteridade. Nesse sentido, no documentário, o enunciador e o ouvinte são duas instâncias apresentadas de forma relacionadas na voz, fundamentando-se pelo caráter performático da expressão cultural envolvida no Jamurikumalu. Tais expressões, dotadas de características próprias e marcadas fundamental pela presença do corpo e da voz, são capitadas de formas diferenciadas pelo cinema e demais meios audiovisuais. Ocorreria aqui uma tradução, na captação da performance, que passa a se constituir dentro das possibilidades audiovisuais. Por nunca ser apreendida em sua 
totalidade "a voz transpõe o homem do corpo, só se manifestando, de maneira fortuita no discurso ou no uso comum" (ZUMTHOR apud OLIVEIRA, 2012: 349). Todavia, existiria uma diferença conspícua entre a expressão da voz tradicional e a expressada pelo documentário, muito embora o estatuto de realidade paire como uma sombra na relação entre filme e o seu espaço de recepção, justamente por estar ligada às circunstâncias imediatas, a performance oral da narração que, segundo Fernandes, está circunscrita à dimensão do "que se faz, e não ao que foi feito" (2003: 38). Ou seja, sua dinâmica é da ordem do inacabado, nômade e geradora de novos sentidos e nuanças, forjando um canal direto para formas de interação contínuas e incapazes de subsumirem-se inteiramente a qualquer mecanismo de reprodução engendrados pela indústria cultural (ADORNO, 1994).

Não obstante, a voz poética tem como fundamento a performance, podendo ser percebida tanto pela presença do corpo quanto pela "concentração dos atos de performances". A voz poética transita, dessa forma, "pela efemeridade e brevidade da expressão performática", instaurando cadeias de significantes baseadas no corpo ou nos meios onde seria possível o trânsito da expressividade de novos significados, por meio de recursos como a metáfora e a metonímia, cuja materialidade é a voz que imprime a modulação no audiovisual (OLIVEIRA, 2012: 351). No que tange o conceito de voz poética em Itãokuegü: as hiper mulheres estariam ainda implícitos a própria percepção de um devir pautado pela mediação e conflito entre a inovação (imagem 7) e a tradição (imagem 8).

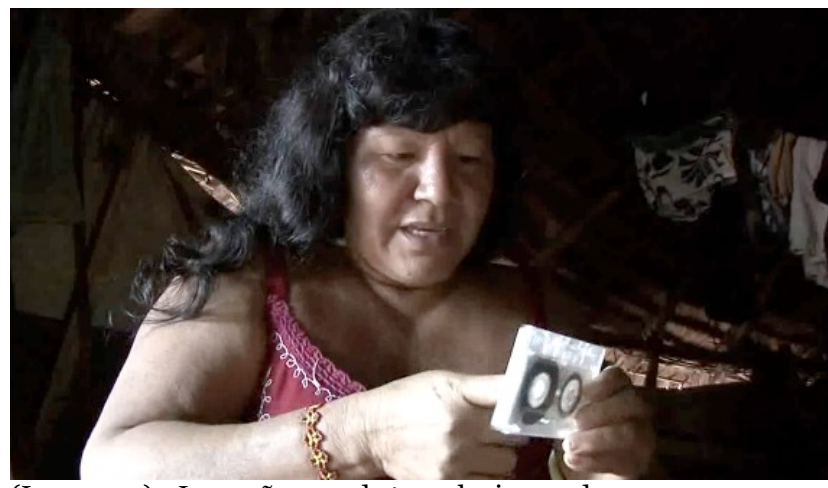

(Imagem 7) -Inovação: uso de tecnologias modernas na transmissão dos cânticos tradicionais.

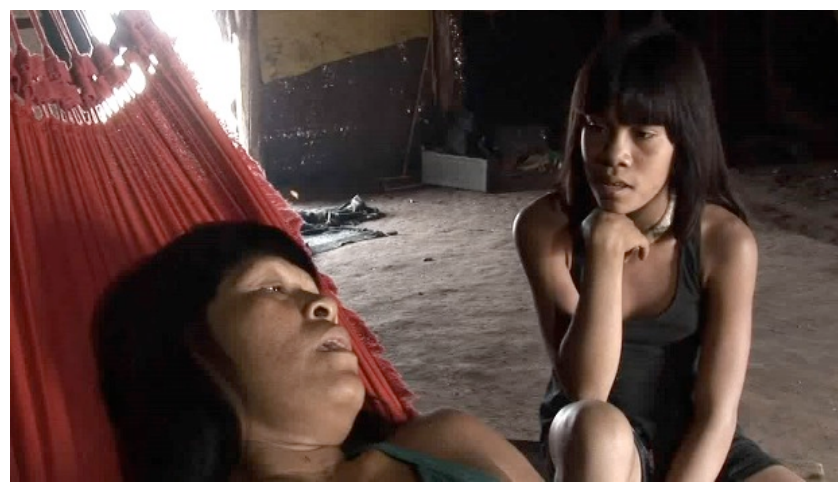

(Imagem 8) - Tradição: aprendizado das canções pela tradição oral. A voz como meio de transmissão.

Mais uma vez, o documentário constrói dois eixos narrativos díspares: de um lado, uma índia pede ajuda ao filho para utilizar um pequeno gravador, recorrendo assim a um aparato tecnológico moderno como ferramenta de apoio que assegurará não apenas a transmissão dos cantos tradicionais as futuras gerações, mas também o registro em uma outra plataforma menos perene que a própria memória. Em contrapartida, em um outro ponto da aldeia, outra índia ensina paciente a neta as canções. Nesse eixo da narrativa duas observações da personagem chamam a atenção: o alerta que ela faz a neta de que o aprendizado das canções é um trabalho lento, árduo e que requer paciência e perseverança; o lamento de que sua filha não teve o mesmo interesse que a neta apresenta em aprender as canções, assegurando assim a perpetuação da tradição da poética oral. Os dois eventos são alinhavados por meio de uma montagem paralela estabelecendo um encadeamento de significantes que se articulariam, à semelhança de um fluxo, unindo e aproximando duas situações diferentes e 
opostos, porém unidas pelo caráter transformativo desse encadeamento. Dessa forma, a voz poética desponta por seu caráter adaptativo dessa expressividade, tendo na performance o elemento modificador.

\section{Três formas de erotismo: corpo, coração e sagrado}

Segundo Bataille (1987), o erotismo está ligado à vida, ao mesmo tempo que está paradoxalmente em constante interação com a dimensão da morte. $\mathrm{O}$ enlaçamento entre vida e morte estaria no bojo do erotismo, posto que é na vida que a morte se encontra dissolvida. Outra ponderação acerca do erotismo que nos apresenta o autor é a de reprodução ligada a perpetuação que, por sua vez,estaria em confronto com a noção de erotismo expressa em termos da relação vida e morte. Bataille ainda relaciona o erotismo a dois outros conceitos: continuidade e descontinuidade. Para ele a reprodução tende a descontinuidade, por possibilitar a formação de novos seres separados entre si por novas descontinuidades. A continuidade seria o atributo do ser, constituído em suas potencialidades e individualidades. É dentro da continuidade que encontrar-se-ia o sentido de finitude do ser. O conceito de memória ou de cultura, expressa em conceitos como cultura tradicional e popular. A perpetuação de uma memória coletiva, tendo por base o tecido cultural, tem no mito um ponto fundamental. Nesse caso, o mito que embasa a expressão cultural, tem na perpetuação um ponto chave. Se por meio do mito podemos observar e apreender as narrativas que dão conta da relação entre homens e mulheres, além do estabelecimento das noções de gênero como categorias fixas a partir da qual a noção de reprodução se estabelece, quando partimos da condição de erotismo para Bataille nos defrontamos com a postulação de que:

\footnotetext{
a reprodução se opunha ao erotismo, mas se é verdade que o erotismo se define pela independência do prazer erótico e da reprodução como fim, o sentido fundamental da reprodução não constitui menos a chave do erotismo (1987: 11).
}

Por conseguinte, o erotismo se diferencia do termo reprodução, envolvendo outro aspecto da vida, que não a perpetuação. Existiria ainda na dimensão do erotismo, segundo o autor, uma relação de brevidade e percepção da finitude contemplado na definição de erotismo relacionado à antinomia entre vida e morte. $O$ erotismo seria assim uma ênfase na vida, em detrimento a concepção da morte. Muita embora tal dicotomia nunca esteja separada no jogo humano, o erotismo evidenciaria a sobreposição da vida frente morte. Para ele, a comunicação seria um rompimento da "descontinuidade" que marcaria a relação entre os seres, estando a alteridade presente no gesto de ruptura com o "abismo" que separa o desconhecido.

Dessa forma, alteridade e comunicação estariam ligados, pois "tentamos nos comunicar, mas nenhuma comunicação entre nós poderá suprimir uma primeira diferença” (BATAILLE, 1987: 11).Ademais, a descontinuidade do ser estaria ligada à sua individualidade, enquanto que a continuidade é o rompimento do abismo que nos transforma em seres descontínuos. Bataille assevera que, o que rege o erotismo é a nostalgia da continuidade, situando os três tipos de erotismo tendo por base a ideia de alteridade, a saber: erotismo dos corpos, erotismo do coração e o erotismo sagrado. Por sua vez, a violência cumpre assim o papel de violar o abismo da descontinuidade, aproximando esse conceito da ideia de comunicação que visa a alteridade. Nesse sentido, a 
violência seria um ato presente na contraposição ao que constitui a descontinuidade como a reprodução. Isto é, a violência assegura em sentido stricto a continuidade.

No documentário, o papel do mito adquire a função de substituir o isolamento da "descontinuidade". A superação do abismo que separa a descontinuidade é constituída pela representação mitológica envolvida na expressão do Jamurikumalu. A voz é um ponto chave nesse elo emocional que envolve os seres descontínuos, em um instante efêmero, e que envolve a comunicação oral e a representação do Jamurikumalu. A alteridade se constitui com o elo entre o ser aos corpos, emissores de vozes, no jogo sexual, ao sentimento de afetividade envolvida no parentesco, bem como ao sagrado representado pelo imaginário mitológico ou a comunicação cultural transcendente baseada na atemporalidade da cultura. Estaria expresso aqui as três concepções de erotismo apresentada por Bataille.

É na passagem da descontinuidade para continuidade dos seres, que o erotismo instaura a violência como a condição fundamental que define o ser descontínuo. A bipartição do gênero constrói seres descontínuos, incompletos. No documentário, podemos encontrar uma alternativa para essa bipartição, por uma alternância conferida aos gêneros. Nesse caso, o gênero feminino é determinado pela construção de um outro papel para o feminino, que passa a ocupar um outro espaço, tanto do ponto de vista das características normativas quanto do poder exercido na comunidade kuikuro. Bataille considera a passagem do estado norma, comum ao desejo erótico, como marca de superação da descontinuidade:

A passagem do estado normal ao de desejo erótico supõe em nós a dissolução relativa do ser constituído na ordem descontínua. O termo dissolução responde à expressão familiar de vida dissoluta, ligada à atividade erótica. No movimento de dissolução dos seres, a parte masculina tem, em princípio, um papel ativo, enquanto a parte feminina é passiva. É essencialmente a parte passiva, feminina, que é dissolvida enquanto ser constituído (1987: 14).

Assim, em Itãokuegü: as hiper mulheres, o erotismo decorre de uma aquisição dos atributos masculinos, por meio dos seus afazeres e dos fazeres, como por exemplo, a apropriação de instrumentos de guerra e trajes masculinos (imagem 9) e o engajamento na luta (imagem 10). É por meio desses atributos que a comunicação entre seres descontínuos se abre, constituindo, por meio dos atributos masculinos, os "canais secretos que dão o sentimento de obscenidade". A obscenidade estaria presente na ideia de "desordem que perturba o estado dos corpos”.

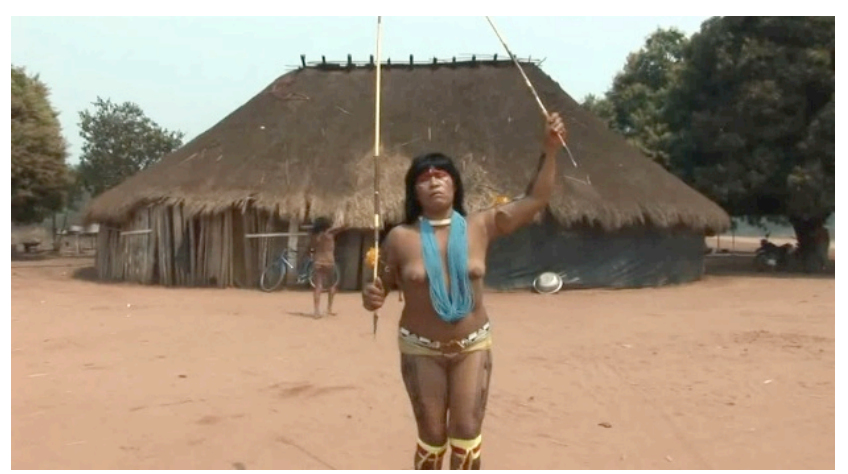

(Imagem 9) Preparação para Jamurikumalu - Apropriação de armas e trajes masculinos

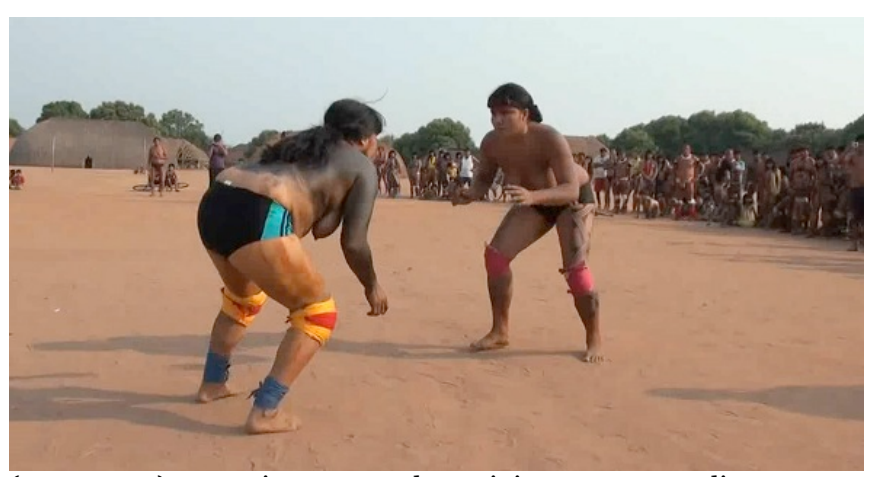

(Imagem 10) - Engajamento em lutas tipicamente masculinas 
$\mathrm{Na}$ esfera do "erotismo dos corações" estaria presente a relação afetiva distintiva da materialidade dos corpos. Segundo Bataille, o erotismo dos corações desenvolve a ideia de dependência afetiva que envolveria a figura dos amantes: apesar das promessas de "felicidade que acompanham, ela introduz inicialmente a confusão e a desordem" (1987: 15). A paixão leva a desordem, que seria a base de uma felicidade constituída na violência. Morte e vida estariam presente na afetividade das paixões: "a posse do ser amado não significa a morte, ao contrário, a sua busca implica a morte”. No documentário, podemos perceber essa relação em passagem como a relação familiar que se estabelece como o ponto inicial da narrativa, na presença da índia Kanu, a única que conhece todos os cantos do Jamurikumalu. É interessante notar ainda a presença do pai como motivador das ações. Na relação familiar estaria presente a dimensão de descontinuidade e continuidade. A busca pelo intento da índia velha subscreve o desejo pela continuidade, seja pela tradição oral, pela memória, mas sobretudo, pela própria performance do ritual que confere as mulheres a autoridade sobre seus próprios corpos e os corpos dos homens.

Com relação ao erotismo no sagrado, presente no sacrifício religioso, Bataille assinala a morte como reveladora. O sagrado apontaria para o rito e solenidade da passagem da descontinuidade para continuidade. A passagem do sagrado para o profano responderia também pela ruptura da descontinuidade dos seres frente ao "abismo", em direção à continuidade. O mito, base para as narrativas apresentadas no documentário, possibilita a ligação dos seres com o sagrado, definidora da relação descontinuidade e continuidade. $\mathrm{O}$ mito possibilitaria uma comunicação entre uma dimensão transcendente e atemporal, de cunho sagrado, sendo uma relação de continuidade, defendida pelo autor. Tal relação parece estar presente também na ideia de cultura tradicional e popular, espaço onde os mitos constitutivos das narrativas estão inicialmente posicionados. O erotismo sagrado opera no regime do equilíbrio, atuando de assim de modo a impossibilitar que nada "perturbe o indivíduo", possibilitando na vida a experiência da morte (BATAILLE, 1987: 17).

A noção de erotismo engendrada pelo documentário é fundamental para constituição da verossimilhança, particularmente no sentido em que as práticas eróticas constituem as bases para encetar a noção de realismo que o documentário intenta alcançar. Assim como as narrativas tradicionais do canto do Jamurikumalu, a construção do corpo indígena também é abordada pelo documentário a partir da realidade vivida no cotidiano do povo kuikuro. Vale observar ainda a maneiro que os corpos são tensionados na relação entre a tradição e o contemporâneo - algo constatado pela relação entre as formas usais dos índios de se vestirem e as formas marcadas pela presença do elemento estrangeiro. Assim como os hábitos, os corpos constituem como o terreno em que conflitam as problemáticas básicas do ser no contemporâneo, e talvez em toda a história dos indígenas na sua relação com a cultura colonizadora. Deve-se levar ainda em conta que muito embora busque-se abordar especificidades da comunidade indígena, essas decorrem do papel do colonizador em nomear e qualificar. A história do índio e a forma como as nomeamos parecem apenas ganhar tal sentido quando mediada pelos paradigmas do colonizador, sendo índio aquilo que o colonizador estabeleceu. 


\section{À guisa de conclusão}

Diante do exposto, remetemos mais uma vez a avaliação de Zumthor ao considerar que, entre um sufixo designando uma ação em curso, mas que jamais será dada como acabada, e o prefixo globalizante, que remete a uma totalidade inacessível, não existente, avoz instaurasua "forma", o improvável (2014: 36). Destarte, a voz converte-se em um vocábulo multidimensional, pois seu desejo de realização é constante e vai além da vontade de conclusão absoluta. Sempre em estado transitório, inacabado, de passagem, a voz imprimida a cada performance deixa fluir um ar de renovação, que se transmuta a cada nova elaboração. Tal conclusão nos remete a consideração de Ferreira na qual "o texto oral, que jamais se preeenche, atua em regime de movência e intercursos de linguagens e códigos expressivos" (FERREIRA, 2011: 12). De modo análogo, o erotismo segue a mesma lógica da incompletude, do incabado, do devir, pois, como assevera Bataille, "somos seres descontínuos, indivíduos que morrem isoladamente numa aventura inteligível, mas temos a nostalgia da continuidade perdida. Não aceitamos muito bem a ideia que no relaciona a uma dualidade de acaso, à individualidade perecível que somos" (1987: 12). Em constante ação vocal $^{5}$, a performance poética reclama a atenção de um crítico, pois é nela que opera o mais íntimo da emoção, daquilo que foi transmitido da boca aos ouvidos. Nesse invólucro, o texto vocalizado se torna arte e faz brotar a totalidade das energias que constitue a obra viva. Zumthor argumenta ainda que esse é o locus qualitativo, zona de operação, "função fantasmática" (2013: 222). Ou seja, o lugar do desconhecimento, mas constituido, ao mesmo tempo, das circunstâncias e contigências que definem o lugar concreto de adesão à consciência.

Nota-se que, diante dessestatus fragmentado, incompleto e cindido tanto da voz quanto do erotismo, o documentário Itãokuegü: as hiper mulheres, por sua vez, esforça-se por estabelecer um elo, mesmo que parcial, precário e momentâneo, entre esses sistemas abstratos de interdição da experiência cultural (a voz, as canções, a tradição oral e a memória) e sexual (o erotismo). Isto é, por meio do estabelecimento de unidades básicas de significação, regras e protolocos documentais que o documentárioaborda tanto as questões das manifestações culturais quanto o próprio status da experiência sexual indígena não normativa com vistas a extrair dessa heterogeneidade de sentidos certa inteligibilidade. Em sentido geral, o documentário assevera a noção do filme em seu sentido lato, como um fato sociocultural multidimensional, especialmente no que diz respeito ao emprego de elementos formais como os protocolos cinematográficos de cunho etnográfico (uso de som direto, câmera na mão, subtração de voice-over narration) aos elementos temáticos como o uso voz feminina como forma de representar o mito envolvido na representação do Jamurikumalu.

Nesse aspecto o cinema aproxima-se do papel de colonizador em nomear e qualificar o diferente tendo por base as especificidades comuns ao elemento do registro colonial. A realidade desenvolvida pelo documentário constrói-se a semelhança do olhar estrangeiro, constituído dentro das regras próprias da cultura de massa, marcado pela síntese e transmissão. Na contemporaneidade, o

5 Zumthor descreve vocalidade como a historicidade de uma voz: seu uso. Segundo o autor, esta pertence a uma longa tradição de pensamento que considera e valoriza a voz como portadora da linguagem, já que, na voz e pela voz, se articulam as sonoridades significantes, cf. A Letra e a Voz: a "Literatura" medieval, 1993: 21. 
vídeo ganha forma de transmissibilidade, constituindo o seu formato e arranjo, tendo por base a transmissão como significante. Existiria aqui uma predileção pelo significante em detrimento ao significado, pois a comunicação de massa no seu processo aglutinador, precisa e privilegia o significante. Tudo se torna significante marcado pela perda do referente relativo aos significados. $\mathrm{Na}$ comunicação de massa o vídeo, assim como a voz, aproxima-se da ideia de simulacro em detrimento a ideia de espetáculo ${ }^{6}$.

Dentro da dimensão da cultura de massa, as três formas de erotismo juntamente com a voz dos cantos, são fundamentais para a construção do realismo do documentário. Podemos aproximar o filme de um documento antropológico, na medida em que o erotismo e a voz funcionariam como simulacro. A ideia do signo sem referência, sendo o erotismo bem como a poética oral desenvolvida pelo documentário. Dessa forma ao abordar o mito, a voz poética faz referência a uma condição liberado dessa obrigação "arcaica" de ter de designar alguma coisa, ele [o signo]se torna enfim livre para um jogo estrutural, ou combinatório, de acordo com uma indiferença e uma indeterminação totais que sucedem à regra anterior de equivalência determinada" (Baudrillard, 1996: 16).

Dessa forma, a síntese dentro de um contexto de universalização das formas é a base para a transmissibilidade envolvida na relação cultura popular e tradicional, como uma expressividade contemporânea em constante relação com a ideia de produto cultural, ligado à indústria cultural e a comunicação de massa. A relação entre as culturas tradicionais e populares dentro do contexto da cultura de massa, apresentar-se-iam como simulacro. Sendo assim, olhar para as formas de transmissão do tradicional para o de massa é antes um olhar para a técnica, e as transformações tecnológicas que possibilitaram a difusão e massificação da imagem como simulacro da realidade cotidiana dos povos indígenas. Diante de um real inalcançável, objeto do realismo, o hiper-real apresentar-se-ia como resultado da relação cada vez mais estreita entre documental e ficcional.

\section{Referências}

Itãokuegü: as hiper mulheres. Documentário, drama. Direção: Takumã Kuikuro, Carlos Fausto e Leonardo Sette. Tecnologia digital. Colorido, estéreo. 80 min. Brasil, 2012.

ADORNO, T. W. A indústria cultural (reconsiderada).In: Theodor W. Adorno. COHN, G. (org). São Paulo:Editora Ática, 1994, p. 92-99.

BAZIN, A. Ontologia da imagem fotográfica. Trad. Eloisa de Araujo Ribeiro. In: O cinema - ensaios. São Paulo: Brasiliense,1991, p. 19-26.

O realismo cinematográfico e a escola italiana da libertação. Trad. Eloisa de Araujo Ribeiro. In: O cinema - ensaios. São Paulo: Brasiliense,1991b, p. 233-257.

6 Silviano Santiago apresenta uma distinção entre espetáculo (manifestação legítima da cultura) e simulacro (entretenimento da indústria cultural), para apontar a predominância das imagens eletrônicas na pós-modernidade. Segundo o autor, tal distinção tornou-se corrente entre analistas que se ancoram nos valores modernistas para compreensão da pós-modernidade, cf. Cosmopolitismos do pobre, 2004: 125. 
BATAIllE, G. Erotismo. Tradução de Antônio Carlos Viana. Porto Alegre: L\&PM, 1987.

FERNANDES, Frederico Augusto Garcia.Entre histórias e tererés: o ouvir da literatura pantaneira. São Paulo: UNESP, 2002.

FERNANDES, Frederico et al. Os trânsitos da voz: de experiências poéticas, religiosas e orais. In: LEITE, Eudes; FERNANDES, Frederico. Trânsitos da voz:estudos de oralidade e literatura. Londrina: EDUEL, 2012, p. 7-20.

FERREIRA, Jerusa Pires. Fausto no Horizonte. São Paulo: EDUC HUCITEC, 1995 .

NICHOLS, Bill. Introdução ao documentário. São Paulo: Papiros editoras, 2005 .

PENAFRIA, MANUELA.Análise de Fìlmes - conceitos e metodologia (s).In: VI Congresso SOPCOM, abril de 2009.

OLIVEIRA, Maria Rosa Duarte de. Explorando o território da voz e da escrita poética em Paul

Zumthor. Revista Fronteiraz, São Paulo, n. 9, dezembro de 2012,p. 349-359.

SANTIAGO, Silviano. Intensidades discursivas. In: $O$ cosmopolitismo do pobre. Belo Horizonte: Editora UFMG, 2004.

ZUMTHOR, Paul. Introdução à poesia oral. São Paulo: Hucitec, 1997. Reimpressão, 2001.

A letra e a voz. São Paulo: Companhia das Letras, 1993. Primeira 